\title{
Freedoms of Collective Speech: A Theory of Protected Communications by Organizations, Communities, and the State
}

\author{
Meir Dan-Cohen $\dagger$
}

\begin{abstract}
Corporations' first amendment rights have received considerable judicial and scholarly attention in recent years. However, corporate speech cannot be studied adequately in isolation; rather, it is more fruitfully investigated within the broader context of collective speech. The author accordingly presents a theoretical framework for dealing with communications by different types of collectivities. The main distinction is between two paradigm collective entities: organizations and communities. Although it makes sense to ascribe speech to both, the grounds for extending constitutional protection are fundamentally different. Whereas communal speech has in and of itself expressive value that raises the first amendment's primary concerns, organizational speech does not. Instead, the latter has only derivative constitutional value, and its protection is parasitic upon other protected interests that the organizations' communications may promote. Moreover, organizational communications themselves are not unitary in nature. The author develops a typology of organizations that distinguishes the reasons for and the desirable extent of protecting their respective communications. Finally the author considers "government speech," demonstrating how the classification of collectivities and their speech rights applies to communications by various state institutions and helps to differentiate the constitutional status of these communications.
\end{abstract}

The recent Supreme Court decision in Austin v. Michigan Chamber of Commerce ${ }^{1}$ puts back on the scholarly agenda, with considerable flourish, a topic whose full constitutional and jurisprudential significance has perhaps not yet been fully assimilated: corporate free speech. In a six-to-three decision, the Court upheld a Michigan statute that prohibits

Copyright (C 1991 by Meir Dan-Cohen. All rights reserved.

$\dagger$ Professor of Law, Boalt Hall School of Law, University of California, Berkeley, and Tel Aviv University, Israel. I would like to thank Jesse Choper, Paul Mishkin, Robert Post, the editors of the California Law Review, and the participants in the Liberty Fund Symposium on Constitutions and Organizations for their helpful comments.

1. 110 S. Ct. 1391 (1990). 
corporations from using general treasury funds for, inter alia, independent expenditures in connection with state candidate elections. ${ }^{2}$ In doing so, the Court appeared to take a step in a direction opposite from its holding some years ago in First National Bank v. Bellotti, ${ }^{3}$ the seminal case that extended first amendment protection to corporate political speech. But though the wavering is clear, assessing whether Austin marks a retreat from Bellotti or an advance over it-was it a step backward or forward-is inuch harder. To inake such an assessment we need a firmer sense of direction in this relatively uncharted area; we need a map - or, less metaphorically, a theory - of the field. The need for such a theory is suggested not only by the divergence between the two cases but also by their coinmonalities: Though their results differ, the two cases share some fundamental assumptions concerning the nature of corporate speech and its constitutional status. These assumptions remain, however, largely tacit. It is the role of theory to try to articulate and scrutinize them.

In this Article, I outline a theoretical framework that aims to ineet these objectives. It should give us a better normative sense of direction in regard to corporate speech and articulate some important assumptions that must be considered in order to understand and evaluate the concept of speech attributed to a corporation. But a theory that attempts these tasks cannot confine itself to corporate speech only. Indeed it seems to me an important drawback of previous efforts in this area that they chose such a relatively narrow focus. ${ }^{4}$ We are unlikely to gain much insight

2. The statute, Mich. CoMp. LAwS ANN. $\$ 169.254(1)$ (West 1989), does not apply to unincorporated labor unions, see Austin, $110 \mathrm{~S}$. Ct. at 1400, or media corporations, see id. at 1401 (citing Mich. CoMp. LAws ANN. $\$ 169.206(3)$ (d) (West 1989) (defining "cxpenditure" so as to exclude media corporation expenditures for any political news story, commentary, or editorial)).

3. 435 U.S. 765 (1978) (5-4 decision) (holding unconstitutional under the first amendment a Massachusetts statute criminalizing corporate expenditures intended to influence voting on state referendum proposals).

4. Much of the literature in this area was spawned by the Bellotti case. See, e.g., Brudney, Business Corporations and Stockholders' Rights Under the First Amendment, 91 YALE L.J. 235 (1981) (criticizing Bellotti and arguing that the first amendment does not preclude any legislative requirement of sliareliolder consent to corporate speech); Fox, Corporate Political Speech: The Effect of First National Bank of Boston v. Bellotti Upon Statutory Limitations on Corporate Referendum Spending. 67 KY. L.J. 75 (1978) (approving of Bellotti and interpreting it as precluding any statutory restrictions on corporate political speech concerning referendum questions); Hart \& Shore, Corporate Spending on State and Local Referendums: First National Bank of Boston v. Bellotti, 29 CASE W. RES. L. REV. 808 (1979) (arguing that corporate campaign activity can have a demonstrable effect and should be limited by legislation modifying or overruling Bellotti); O'Kelley, The Constitutional Rights of Corporations Revisited: Social and Political Expression and the Corporation after First National Bank v. Bellotti, 67 GEO. L.J. 1347 (1979) (approving the result in Bellotti but criticizing its reasoning); Patton \& Bartlett, Corporate "Persons" and Freedom of Speech: The Political Impact of Legal Mythology, 1981 WIS. L. Rev. 494 (arguing tliat Bellotti and its successors rest not on neutral legal principles as the Court presents them, but represent a political choice); Note, Political Contributions-First National Bank of Boston v. Bellotti-Another Hurdle for Shareholder Protection, 4 J. CoRP. L. 460 (1979) (authored by Daniel D. Dykstra) (examining in 
into issues of corporate speech unless we locate them in the broader context of collective speech. Hence, the theoretical framework that I propose analyzes the speech rights of various collectivities of which business corporations, such as those involved in Austin and Bellotti, are just one breed. 5

The main distimction I draw is between two paradigm collectivities-organizations and commumities-and the speech they produce. I discuss organizational speech first, in Section II. Subsections A and B are designed to establish "organizational speech" as a sound category for purposes of constitutional analysis, distinct from individual speech and calling for different protection than the latter deserves. This category can, however, be refined by subdividing orgamzations, in terms of the nature of their communicative activities, into some further subcategories. Accordingly I distinguish between utilitarian organizations, of which business corporations are the main example (discussed in Subsection C), expressive organizations, and protective organizations (both discussed in Subsection D). In Section III, I juxtapose communal speech and organizational speech, arguing that though communal speech too is collective in nature, it resembles, for constitutional purposes, individual self-expression much more than organizational speech does. In assessing the appropriate constitutional protection of communications by the various collectivities that I distinguish, I use a typology of speech rights that I develop in Section I. Finally, in Section IV, I apply this general franework to government speech with the hope that the suggested approach will help illuminate this rather din corner in the area of collective speech. ${ }^{6}$

the wake of Bellotti common law protections for minority shareholders of corporations that make political expenditures); Note, The Corporation and the Constitution: Economic Due Process and Corporate Speech, 90 YALE L.J. 1833 (1981) (interpreting Bellottl as a return to economic due process jurisprudence that should be overturned).

5. Indeed, "corporate speech" raises basic issues of the nature of legal protections in an organizational society. I have elaborated a general approach to these issues in M. DAN-CoHEN, Rights, Persons, and Organizations: A Legal Theory for Bureaucratic Society (1986). In classifying business corporations as a breed of organizations, I am referring to corporations of sufficient size and complexity to warrant the application of an organizational vocabulary and theory to them. The mere legal status of incorporation is not dispositive here for such a classification.

6. Since the word "theory" is used, especially in law, to denote very different creatures and raises very different expectations, I should perhaps say a word about my use of the term. This Article is "theoretical" in the sense that it uses fairly abstract concepts, often borrowed from other disciplines, for the purpose of a systematic representation and elucidation of a rather large area of the law. But abstraction and systematization require a good deal of idealization and simplifieation. Consequently, the validity of the theory's normative conclusions depends on the simplifying assumptions on which the theory rests. The theory, therefore, does not issue an "all things considered" recommendation for action (including, of course, judicial action). Rather, by casting its light from a somewhat unusual angle, the theory accentuates certain features of the landscapecertain obstacles, pitfalls, or opportunities-that may otherwise go unnoticed. But the indefinite article " $\mathrm{a}$ " conjoined to "theory" in my subtitle is all-important. To be sure-footed, practically 
The best summary I can offer of the conclusions that I reach in this study is already provided in the form of a table in the Conclusion. Perhaps by way of a general orientation, the reader may want to take a glance at it now, though I fear that at this stage it will prove quite uninformative, whereas by the time it is reached in due course it will seem rather otiose.

\section{I \\ RIGHTS TO FrEe SPEECH}

Some preliminaries to set the stage. First, I shall present my argument within a normative framework that by now has become familiar, though I hope not quite to the point of breeding contempt. It is the description of the liberal tradition in terms of the juxtaposition of utilitarianism and deontology, the latter mainly of the Kantian variety. The application of this framework to American law is based on the claim that we can understand this body of law, its doctrines and institutions, in terms of both normative points of view. Seen from the utilitarian perspective, the law is primarily concerned with the promotion of social welfare. The main criterion for legal rules and the main guideline for legal decisions is, according to this view, the tendency of these rules and decisions to maximize social utility. The second point of view considers the law as primarily committed to the ideal of individual autonomy. Accordingly, the chief purpose of the law is to provide adequate protection to individual rights, understood as expressions and safeguards of the individual's autonomy, irrespective of the general societal consequences of such protection.

While various aspects of the law are anenable to interpretation in terms of either approach, one important concept arises out of the tension between the two. This is the concept of a "right" in the strong sense, as understood and defended by Ronald Dworkin. ${ }^{7}$ This concept of a right is essentially "anti-utilitarian" since the purpose of recognizing such rights is to insulate certain aspects of persons and their lives from the encroaching demands of society's cumulative welfare, thus securing individuals' autonomy and respecting their dignity. Although it is also possible to think of legal rights in utilitarian terms, in discussing freedom of speech I shall focus exclusively on the "strong" meaning of right just explained. To carry the weight normally assigned to it, freedom of speech must be understood as an autonomy right-embodying or protect-

speaking, in any field, one must master and integrate numerous perspectives and points of view such as the one presented here. In this way theory can inform practice, though it should not be expected to rule or dictate it.

7. R. DWORKIN, TAKing Rights Seriously 188-92 (1977). 
ing some fundamental aspects of personhood vital to one's dignity and exercise of autonomy.

However, even withm these somewhat artificial strictures freedom of speech as currently understood remains a complex right. Without hoping to do justice to all these complexities, I must introduce two further distinctions that will be central to my argument. First, freedom of speech is said to be supported by two sets of interests: those of the speaker, which I will call the "active" aspect of free speech; and those of the listener, which I will call the "passive" aspect. The active right to speak is linked to the ideas of self-expression and self-realization, both perceived as constituents of, or preconditions for, flourishing personhood. Arguments based on the histener's autonomy, on the other hand, emphasize the importance of the free availability and unlimited accessibility of information, ideas, and points of view for one's ability to form independent, informed, and intelligent judgments. In this respect, speech is thought of as peculiarly bound up with the idea of individual autonoiny. Whereas a certain degree of satisfaction of other imdividual needs and interests can be seen as a necessary precondition of an individual's ability to lead an autonomous life, the continuous flow of uninhibited discursive activity is essential to the ceaseless formation and revision of one's independent judgments, which are constitutive of the autonomous life itself. ${ }^{8}$

The second distinction is between two kinds of rights. A right may be recognized in $A$ out of concern for $A$ himself. In sucl a case, $A$ lias what I shall call an original right. A right in $A$ may also result from a concern not for him but for $B$. In this case, $A$ will be said to have a derivative right. A guardian, for example, may be given such rights as are necessary for the effective execution of her role. She may, for instance, have a right to reimbursement for expenses incurred in carrying out her duties. However, the reason for the right to reimbursement lies in the concern for the ward's interests, and only derivatively in the concern for protecting the guardian's interests.

By applying this distinction to active and passive speech rights, we can see that in addition to the original right to speech-a right to selfexpression-we can inagine protection by the first amendment for very

8. Though this picture of the first amendment is incomplete, it is not as limited as it might perhaps seem at first sight. Much of what is of value in the political conception of free speech, as advocated by Professor Meiklejohn, is actually contained in a conception focusing on autonomy and self-expression-political participation can itself be seen as a particularly important form of selfexpression and its value derived from that of individual autonomy. See generally A. MEIKLEJOHN, Political Freedom 3-89 (1965) (Part One, entitled "Free Speech and Its Relation to SelfGovernment," elaborating a concept of political freedom dependent on the ability of the people to exercise their power of self-governance for which free speech is an essential condition). But see Scanion, $A$ Theory of Freedom of Expression, 1 PHIL. \& PuB. AFF. 204 (1972) (criticizing as "artificial" Meiklejohn's view that freedom of speech is based upon political freedom). 
different reasons. First, concern for the listener's autonomy, which underlies the passive aspect of freedom of speech, suggests a derivative right in the speaker not to be interrupted in her communications. I will call such a right a passive derivative speech right. Secondly, first amendment protection can extend to someone other than the original speaker out of concern for that speaker if granting such protection to the other person promotes or protects the original speaker's self-expression. A publisher of a book, for example, may deserve such protection based on his contribution to the author's self-expression. In such a case the publisher would have an active derivative speech right.

\section{II}

\section{ORganizational SPEech}

\section{A. Can Organizations Speak?}

The purpose of this.section is to explore the speech rights of different kinds of organizations. But before we can proceed, we must first address a threshold question that arises with respect to all of them: Is organizational speech distinct from the cominunications of particular individuals?

Indeed, one line of criticisin of the Supreme Court's willingness to extend first amendment protection to corporate political speech denies that there really is such a thing as corporate or organizational speech: Only individual human bemgs, this argument claims, can communicate. Talk about organizational or corporate speech is, accordingly, seen as just a misleading way of describing the views of managers combined with their decision to expend corporate resources for their dissemination. ${ }^{9}$ To take a different view, to take seriously the notion that organizations can speak, is to lapse into hopeless anthropomorphism or to subscribe to an uninviting holistic metaphysics populated with such notoriously spooky phenomena as "group mind." However, this argument continues, if the messages transinitted by an organization are always attributable to specific individuals, the suppression of such organizational speech would result in no loss to the public in coinmunicative content. The same ideas and information would remain in public circulation, with the additional advantage that their individual sources would be exposed rather than hidden behind an organizational veil.

I think, nevertheless, that the Court's willingness to entertain the distinct reality of organizational speech is sound and can be upheld without resorting to either anthropomorphism or holistic metaphysics. The

9. See, e.g., O'Kelley, supra note 4, at 1373 ("Corporate communication does not exist; only individuals can have ideas."); see also Brudney, supra note 4, at 248 (analyzing corporate speech as the result of decisions of individuals within the corporation who authorize the corporation to "speak"). 
idea of organizational speech can be made intelligible by two related, but distinguishable concepts: organizational decisionmaking and organizational roles.

\section{Organizational Decisionmaking}

Organization theorists characterize formal organizations most frequently by the presence of a decisionmaking process. The focus on decisionmaking as a central and essential organizational activity draws attention to the crucial importance that information plays in organizations. The idea of decisionmaking implies the capacity to perform such functions as gatherimg, registering, recording, decoding, and disseiminating information. These information-related functions are generally imputed to the organization, rather than to some specific individuals, because the total information that leads to a certain decision, action, or product is not normally possessed by any single individual, nor is it directly and solely related to the coinbined knowledge possessed by a number of identifiable individuals. The processing of the information within the organization significantly affects the information itself as well as the final decision. What information is gathered, to whom it is disseminated, how it is decoded, and how it is combined and brought to bear on the final outcome critically depends on the structure of the organization, on the presence or absence of particular units or positions in it, on the relevant standard operating procedures, as well as on the presence of "noise" that imtroduces an elenient of randomness into the processing of information. ${ }^{10}$

Furthermore, in speaking of an organizational decision we presuppose the existence of some organizational preferences. Here too, it is sensible to impute preferences to the orgamzation itself. Even though the organizational preferences are ultimately the product of some individuals' preferences, it may often be impossible to account for the organizational decision purely in terms of the latter. Two lines of argument discourage the effort to reduce the organization's preferences (as embodied in its decisions) to their individualistic constituents. One line is based on the coalition view of the organization, which depicts the organization as a set of coalitions in which decisionmaking is essentially a bargaining process among various groups with divergent and often conflicting interests. Decisions are accordingly characterized as the "political

10. On the role and nature of information processing in organizations, see generally $R$. BonCzeK, C. Holsapple \& A. Whinston, Foundations of Decision SUPPORT SysTeMs (1981) (discussing decisionmaking systems and theories); H. WilenskY, Organizational. INTELLIGENCE: KNOWLEDGE AND POLICY IN GovernMENT AND INDUSTRY (1967) (analyzing organizational intelligence as a form of information processing in several contexts). 
resultants"11 of these complex bargains, achieved in part by logrolling and strategic behavior.

Social choice theory articulates more generally the obstacles, both practical and conceptual, to aggregating individual preferences into a collectively rational choice. ${ }^{12}$ Arrow's famous "Impossibility Theorem" presents a good example. It proves that under certain plausible conditions no voting procedure is available to translate individual preferences into transitive collective orderings. ${ }^{13}$ Thus a group's decision one way rather than another inay not reflect the actual preferences of the group's individual members, but may instead result from nothing deeper than the accidental (or mainpulated) arrangement of the agenda. A similar inessage is contained in Thomas Schelling's book Micromotives and Macrobehavior, ${ }^{14}$ which examines various ways in which rational behavior on the part of individuals results in a pattern of group conduct that is irrational or suboptimal. His thesis can be stated in reverse to support my point about the relation between individual preferences and collective behavior: Based on the observation of certain collective positions or decisions, we cannot confidently infer the underlying individual preferences or motivations that generated it.

To portray organizations as "intentional systems"15 possessed of "organizational intelligence" may be a cogent way of expressing the dual message that organizations make decisions infused with cognitive content that are simultaneously the product of widely dispersed informational sources and diffused mdividual interests and attitudes, all mediated by structures, processes, and chance, in ways that defy translating or tracing the organizational decision into its individual sources.

These observations illustrate one of the inain imphicit insights of organization theory. Rather than trying to fully reduce organizational

11. [R]esultants in the sense that what happens is not chosen as a solution to a problem but rather results from compromise, conflict, and confusion of officials with diverse interests and unequal influence; political in the sense that the activity from which decisions and actions emerge is best characterized as bargaining along regularized channels among individual members of the [organization].

G. Allison, Essence of Decision: Explaining the Cuban Missile Crisis 162 (1971).

12. See, e.g., Buchanan, Individual Choice in Voting and the Market, 62 J. PoL. Econ. 334, $341-42$ (1954) (arguing that individuals act rationally only if they make choices for themselves, but that there are a number of difficulties to achieving a rational choice if they participate in collective decisions).

13. See K. Arrow, Social Choice and Individual Values $2-3$, 59 (2d ed. 1963). For a critical discussion, see R. LUCE \& H. RAIFFA, GAMES AND DECISIONS 327-70 (1957) (describing Arrow's theorem and discussing schemes to circumvent it).

14. T. SChelling, Micromotives aNd MACrobehavior (1978).

15. See D. Dennetr, Conditions of Personhood, in Brainstorms: Philosophical Essays ON MiND AND PsYCHOLOGY 267, 271 (1978) (defining intentional systems as systems or organisms whose behavior can be explained by reference to beliefs, desires, and intentions); see also French, The Corporation as a Moral Person, 16 AM. PHIL. Q. 207, 212-15 (1979) (discussing the relation between organizational decisionmaking and the ascription of intentionality to organizations). 
phenomena into their individual constituents, organization theory explains, in essentially individualistic terms, our inability to perform such a reduction. Fainiliarity with the pecuharities of group decisionmaking, in my exainple, accounts for the gap between individual and collective rationality. By thus spelling out the grounds for, and emphasizing the inevitability of, imputing global properties to organizations, organization theory makes us soinewhat inore confident and clearheaded in using the ordinary holistic, reifying language we commonly apply to organizations. The intelligibility of such holistic terminology we daily use need not accordingly depend on a metaphorical personification of the organization nor on soine far-reaching inetaphysical commitments.

This general observation also applies to and supports our ascription of speech to the organization itself. Speech, no less thian cars or widgets, can be an organizational product. Like other organizational activities, speech inay also be a global, nondistributive plienomenon, elnanating from the organization without being traceable or reducible to individual utterances. Indeed, in light of the preceding cominents on decisionmaking as an essential feature of the organization, speech is particularly likely to be such a nonreducible organizational phenoinenon.

\section{Organizational Roles}

The foregoing description of organizational speech as the joint and undifferentiated product of complex decisionmaking processes does not always apply, however. Often the speech we ascribe to the organization is actually uttered by a specific, identifiable individual. Surely in sucli a case, it might be thought, treating and protecting the speech in question as a matter of the individual speaker's self-expression would be adequate, whereas imputing that speech for purposes of constitutional protection to the organization creates botli inystification and redundancy. My aim in this section is to dispel this impression and to show that even in the seemingly simpler case of a specific individual's utterance, the organizational perspective cannot be avoided and that constitutional analysis in terms of the individual's self-expression would not do. In order to show this I will need an additional piece of theoretical equipinent-the concept of roledistance-which I borrow, witl some modifications, from Erving Goffman. ${ }^{16}$

The term "role-distance" belongs to the vocabulary of the self as well as to the vocabulary of social role and serves as a bridge between the two. It is part of a dramaturgical innagery of the self, according to which the self consists, at least in part, of the social roles that it enacts. The special insight that the concept of role-distance imports into this picture

16. See E. Goffman, Role Distance, in Encounters: Two Studies in the Sociology of INTERACTION 85 (1961). 
consists of the recognition that the self can locate itself, metaphorically speaking, at variable distances from the different roles that it occupies. Identification with a role is a matter of degree, and, depending on the degree of identification, a given role may be more or less integrated with and constitutive of a particular self. This is the basic idea, and though my account of it must remain simplified, let me add a few more details.

Exactly what identification with a role, or detachment from it, consists in is a difficult matter, but the following criterion provides at least a proxy or approximation. When I fully identify with a role-when the role-distance, to further exploit the spatial metaphor, is reduced to zero-I enact the role "transparently"-that is, without an explicit awareness of the role's requirements and the fact that I am fulfilling them. By contrast, the presence of role-distance is marked by self-consciousness-by an explicit awareness that I am playacting; that I enact a certain role by responding to its requirements and expectations.

Identification and detachment are not fixed properties of roles. The distance between a person and a role can fluctuate over time. It is also not the case that some roles must be worn tightly whereas others are held at a distance by all their takers. I can become at times self-conscious about, and distanced from, every one of my roles, just as it seems that every role can, in principle, be enacted transparently by someone. Still a certain degree of uniformity in the style of enacting different roles exists, and so some generalization regarding role-distance is possible. Some roles call for greater identification than others. Certain roles are in general more likely to be enacted at a distance than other roles. So it is meaningful, though not altogether accurate, to speak in general terms about "detached" as opposed to "nondetached" roles. Moreover, the appropriate distance between self and role-that is, whether a detached or a nondetached performance of a role is appropriate-is itself a normative matter, regulated by social norms.

Let us now consider in the light of these observations a typical organizational role, say that of an AT\&T operator. Let me draw attention to a few aspects of this role. Notice that it would be altogether appropriate for the operator to keep that role at a distance. He can be an accomphished operator even though he just, as it were, goes through the motions of being an operator (as long as, of course, he goes through them well enough). One important implication of, as well as evidence for, this observation concerns the source, relative to the self, of the normative guidance provided by the role. Insofar as the role that $I$ enact is a detached one, I experience the role's imperatives as external, and thus potentially as constraints. Potentially, because the role's requirements may coincide, of course, in .general or in any specific instance with my wants and desires. But this coincidence is, in principle, adventitious; it is 
not an essential part of my relationship to a detached role. If the operator is to perform his tasks, he must be motivated somehow-bribed or coerced-to do so. The most common combination used to this effect contains elements of both kinds of inducement. Performing a detached role is therefore not, as such, a display of autonomy. ${ }^{17}$

These characteristics of the operator's role are reflected, and further accentuated, when we consider the operator's speech. Let me focus on a very simple and common speech act: the display of courtesy mvolved in the expression of gratitude. Indeed, if courtesy were measured by the frequency with which one utters words of politeness, the operator would surely be a world champion in the field. As anyone who has ever needed his or her assistance knows, the operator concludes eaclı exchange, no matter how sliort or trivial (and these exchanges tend to be both), by proclaiming: "Thank you for using AT\&T."

Though on the surface this utterance looks (or ratlier sounds) no different from any ordmary expression of gratitude, its unusual characteristics are easy to uncover. First, the operator's utterance is in compliance witlı his role's imperatives, and like the other imperatives associated with a detached role, the duty to say "thank you" also remains external to the individual performer. Since the operator has no internal motivation to speak, sucli motivation must be provided for from the outside by the organization in the form of either inducement or coercion. A recalcitrant operator surely would be threatened witl dismissal if he fails to perform the incantation, irrespective of the earnestness of his belief that the required practice is silly and inappropriate for him or for the role he plays. Or imagine the operators going on partial strike, their umion decreeing: "No more of this 'thank you' silliness until we get a raise." It would seein altogether appropriate for AT\&T to meet the union's demands by actually paying the operators to perform that particular aspect of their task. It is only by such external organizational inducement or compulsion that the operator can be expected to perform the utterance.

The detached nature of the operator's role issues in, and is corroborated by, what may be described as a rather remarkable hinguistic aberration of his speech act: its failure to comport with the requirement of sincerity. Professor John Searle, a leading speecl1-act theorist, maintains that the requirement of sincerity is a condition for the successful performance of a speech act. As evidence for this view, he observes that "it

17. I say "as such" because depending on a more detailed theory of autonomy, as well as on the nature of the second-order reasons one may have for enacting the detached role, its enactment may count as autonomous after all. The important point is that the individual's very engagement in the specific tasks of a telephone operator does not purport to express the operator's own will. Contrast the way that properly discharging parental duties is ordinarily supposed to be a manifestation of the parent's own will. See infra Part III.A. 
is linguistically unacceptable (though not self-contradictory) to conjoin the explicit performance verb with the denial of the expressed psychological state."18 By uttering the expression "thank you," for example, one does not quite assert that one is grateful, so that one is not involved in a contradiction if one adds to that expression the words 'but I'm not really grateful." Yet such a locution ("thank you, but I'm not really grateful") is undeniably odd, and on Searle's view this linguistic oddity attests to the fact that the normal use of an expression such as "thank you" is taken to satisfy the condition of sincerity-that is, it presupposes, and is taken to express, the actual psychological state of gratitude.

However, in the operator's case we can find an opposite and equally instructive oddity. It would be quite ludicrous for the overly zealous telephone operator to say "Thank you for using AT\&T," and then add "and I really mean it." Since the motivation for the utterance arises from a source external to the operator-the operator is detached from his role, and the obligation to make the utterance is imposed by the organization-he is not expected to entertain any relevant state of mind with regard to the utterance.

To be sure, not all organizational roles are as strictly circumscribed as is the operator's role, and they may involve greater leeway in the formulation of the appropriate communications than the operator is afforded. Yet the example of the operator helps accentuate features that are common to all organizational position-liolders and their speech acts. Statements made by organizational position-holders carry with them the explicit or implicit understanding that they are made "from the corporate point of view" and in one's "official capacity." Consequently, professions of sincerity (akin to the operator's inappropriate "I really mean it" assurance) are in such cases out of place. They would smack of what we might call, borrowing Sartre's well-known expression, "bad faitll," by which I mean an excessive identification with what is supposed to be a detached role. ${ }^{19}$ Sincerity, which is one of the most basic conditions for the successful performance of an individual speech act, simply does not belong in the organizational language game.

This is not the place to attempt a full account of the relatively high degree of role-distance that at least in this society is deemed appropriate in bureaucratic orgamizations. But we can at least glimpse in passing one explanation-albeit a highly speculative one--that relates to the instrumental nature of these entities and to the prevailing ethical ambivalence

18. J. SEARLE, $A$ Taxonomy of Illocutionary Acts, in EXPRESSION AND MEANING: STUdies IN THE THEORY OF SPEECH ACTS 1, 4-5 (1979).

19. Sartre's own use of this term is broader, roughly designating any enactment of a social role that is oblivious to the contingency of one's being in that role and to the choice that is inescapably involved in assuming the role. See J.-P. SARTRE, BEING AND Nothingness: AN ESSAY ON Phenomenological Ontology 47-70 (H. Barnes trans. 1957). 
toward such instrumentalism. By isolating the self from the organization role, role-distance shields the self, to a degree, from the blatant instrumentalism of these organizations. At the same time, role-distance gives these organizations as well as their members a certain flexibility and adaptability that is likely to be conducive to the organization's operational success. Detached roles can be, if necessary, redefined or reassigned without thereby playing havoc with the selves of the roles' individual bearers.

The characteristics of utterances made by an individual in the performance of a detached role that $I$ have mentioned-call such utterances "detached speech"- have obvious constitutional implications. As we have seen, detached speech is an essentially impersonal production: It is externally inotivated, and being exempt from the requirement of sincerity, it is avowedly cut off from the speaker's own identity and psychological state. It is therefore both futile and fallacious to suggest that such speech can be extracted from the organizational context and to recommend that it be viewed instead as uttered by the speaker in her "individual" capacity and on her own behalf. She inay be neither inclined nor able to perform the same speech acts outside of her office hours, so to speak. Failure to recognize that such speech is inade essentially in the speaker's official capacity and is thus irreducibly "organizational" in nature, and the consequent failure to protect it as such, may result in this particular inessage being lost. ${ }^{20}$ On the other hand, ascribing such detached speech, when performed, to the individual speaker will result in investing that speech with values of self-expression and autonomy that it does not have and will qualify it for a level of constitutional protection it does not deserve.

\section{B. Organizational Speech and Individual Speech}

Recognizing that organizations can speak is only the first step toward confronting the real problem of the constitutional protection of their speech. The problem is this. The recognition that organizational speech does exist seems to lead to the conclusion, unpalatable to many, that such speech deserves the same protection as individual speech. Both the Supreme Court and commentators have attempted to avoid this conclusion in regard to corporations by finding reasons for inhibiting corporate speech that allegedly do not apply to individuals. But the attempt has not been successful.

Consider the reasoning in Austin v. Michigan Chamber of Commerce. ${ }^{21}$ By pointing to two corporate characteristics that supposedly

20. For a discussion of a corresponding fallacy in the case of communal speech, see infra text accompanying notes 76-79.

21. 110 S. Ct. 1391 (1990). 
justify inhibiting corporate political speech, the majority's opinion tries to reconcile a recognition that "expressive rights are implicated in this case"22 with a desire to legitimate the government's curbing of these rights. First is the consideration that

" $[t]$ he resources in the treasury of a business corporation ... are not an indication of popular support for the corporation's political ideas. They reflect instead the economically motivated decisions of investors and customers. The availability of these resources may make a corporation a formidable political presence, even though the power of the corporation may be no reflection of the power of its ideas."23

As its second argument, the Court mvokes "the unique state-conferred corporate structure that facilitates the amassing of large treasuries."24 Since the state conferred the benefit, it can also regulate or inhibit that benefit.

But as the dissent is quick to point out, both of these observations could apply to John D. Rockefeller as well. Individuals can also amass fortunes by taking advantage of governmentally created structures and opportunities (including, of course, by holding shares in corporations), and yet "[i]t is rudimentary that the State cannot exact as the price of those special advantages the forfeiture of First Amendment rights."25 Similarly, the fortunes amassed by wealthy individuals also give them pohtical power that is "no reflection of the power of [their] ideas,"26 a fact that would hardly make it "lawful to prohibit men and women whose net worth is above a certain figure from endorsing political candidates." 27

The other justification that has been advanced by commentators in support of government restrictions on corporate political speech focuses on the relation between the corporation's speech and the rights of its shareholders. The justification exists im both a strong and a weak form. Neither withstands critical appraisal.

The stronger version invokes the dissident minority's first amendment rights. The protection of corporate speech, in the absence of unanimous shareholder support, violates the dissenting shareholders' first amendment rights because it forces them to contribute to the expression of views they do not hold. However, the argument fails because it greatly exaggerates the link between the shareholders and the large corporation. No one is likely to identify the views of any individual shareholder with

22. Id. at 1395 .

23. Id. at 1397 (alteration in original) (quoting Federal Election Comm'n v. Massachusetts Citizens for Life, Inc., 479 U.S. 238, 258 (1986)).

24. Id. at 1398.

25. Id. at 1408 (Scalia, J., dissenting).

26. Id. at 1397.

27. Id. at 1409 (Scalia, J., dissenting). 
the policies pursued by General Motors, whether or not those policies are publicized or "spoken" by the corporation. Just as customers who sometimes express their displeasure at corporate policies by boycotting the corporation's products, shareholders too may wish to publicly express their dissent. But the notion that corporate policies or expressions violate in any way dissenting shareholders' freedom of speech any more than they violate such rights of disgruntled customers or employees completely overlooks the nature of the large modern corporation. ${ }^{28}$

The weaker version of the argument fares no better for similar reasons. This view does concede that minority shareholders can easily disassociate themselves from offensive corporate speech by selling their corporate stock, yet it finds a "compelling state interest ... in the need to protect individual stockholders against being forced to clioose between contributing to political or social expressions with which they disagree or foregoing opportunities for profitable investment." ${ }^{29}$ This state interest is protected by imposing a sliareholder unamimity requirement as a prerequisite for free corporate speech.

So innagine a wealthy businessman in your community who is paying high interest on the money you and other local folks lend him. Unfortunately, he is also a known fascist, and he uses the money he borrows (or the profit he makes on it) to publicly express his despicable political views. Does he thereby compromise your rights by forcing you "to choose between contributing to political or social expressions with which [you] disagree or foregoing opportunities for profitable investment'? The obvious negative answer applies, it seems to ine, with equal force to the case of the shareholder and the large corporation. As soon as the shareholder is conceived of as a mere investor, which he is within the context of the state-interest argument, he is no longer entitled, as a matter of right, to investment opportumities free from any undesirable political ramifications.

It is evident that all these attempts to legitimate governnent's curtailment of corporate speech fail in the same way and for the same reason. Their failure is in their overinclusiveness: If consistently applied, these arguments would also inhibit individual speech. The source of the

28. The perception of the shareholder in the large modern corporation as essentially an investor is echoed in the majority opinion's argument in which a distinction is made between First Nat'1 Bank v. Bellotti, 435 U.S. 765 (1978), and Abood v. Detroit Bd. of Educ., 431 U.S. 209, 236-37 (1978) (holding that a law requiring public school teachers to pay a "service charge" to the union although they refused to become members violated their first amendment rights to the extent that the service charges were used to finance union expenditures for causes not germane to its duties as a collectivebargaining representative). In contrasting shareholders to employees bound to the union by an agency-shop arrangement, the Court in Bellotti points out that "the shareholder invests in a corporation of his own volition and is free to withdraw his investment at any time and for any reason." Bellotti, 435 U.S. at 794 n.34.

29. Brudney, supra note 4, at 268. 
failure is this: All of the arguments presume that once a corporate activity qualifies as speech, it assumes the same constitutional status and is entitled to the same constitutional protection as a corresponding activity carried out by an individual. The various arguments consist then in attempts to identify different "compelling state interests" that should be allowed to override the legal protection due to speech. The trouble is that the particular "compellimg state interests" apply with equal normative force to restrictions on individual speech.

If we want to improve on these arguments, we must take a closer look at their common underlying assumption that equates, for the purpose of constitutional protection, organizational speech to individual speech. It is at this more fundamental level that the barrier between the legal treatment of individual and organizational speech should be erected. This is not difficult to do.

As I have already mdicated, the very traits of organizations that make reductionism inappropriate and justify ascribing speech to the organization itself also nrark that speech as distinctively impersonal. If we thus consider orgamizational speech im hight of our conception of freedom of speech as an autonomy right, ${ }^{30}$ we can conclude that organizations do not have an original active right to free speech. The values of self-expression and self-realization that normally underlie the speaker's original first amendment right are not implicated in the type of impersonal production that can be ascribed to the organizational entity.

But this negative conclusion, of course, does not exhaust the possibihities of applymg the first amendment to organizational speech: we must still explore ascribing to organizations other types of speech rights that I have distinguished in Section I. As the two following subsections demonstrate, different categories of organizations will be the bearers of different kinds of speech rights, though no organization enjoys active original speech rights designed to protect individual self-expression.

\section{Utilitarian Organizations-The Case of Corporate Speech}

Organizations are instrumental, goal-oriented, social entities. The goals pursued by an organization are the source of its social legitimacy and anchor its normative-specifically legal-claims. Seen in this light, business corporations exemplify an important normative category of organizations. The goals of business corporations relate, generally speaking, to the production and distribution of goods and services. At least ideally, all of a corporation's activities-including its communicative activities - are to be construed, rationalized, and assessed in terms of their contribution to these ends. In this way, the goals that ground busi-

30. See supra notes 7-8 and accompanying text. 
ness corporations' social legitimacy concern their contribution to society's economic welfare. I will thus designate corporations and other organizations that perform a similar social function as utilitarian organizations.

Although business corporations are not the only utilitarian organzations, they are by far the most common. Focusing on corporate speech is therefore a good way to consider the somewhat broader category of speech by utilitarian organizations. The import for free speech of classifying an organization as "utilitarian" will, however, fully emerge only in the next subsection, when I contrast speech by such organizations with that produced by other classes of organizations.

The classification of corporations as utilitarian organizations corroborates the general conclusion that they lack original, autonomybased, speech rights. The normative status of corporate speech is to be assessed in light of the contribution that corporate communications make to the attainment of the corporation's goals. Since the goals that ground a business corporation's social legitimacy are of utihtarian value, so also is speech that serves their ends. This, of course, may justify extending certain protections to corporate (and other utilitarian organizations') speech for utilitarian reasons. Indeed, the legal treatment of "commercial speech" may be understood in part in these terms. But this possibility falls outside the scope of this essay. As I indicated earlier, my present interest is with speech rights in the strong, anti-utilitarian sense; the corporation's goals as I have characterized thein do not support such rights.

But the conclusion that utilitarian organizations lack an original active right to free speech does not strip corporate speech of all constitutional protection. As I have indicated in Section $I,{ }^{31}$ speech can also be protected on behalf of the listeners' right to hear it. In this case the speaker has a passive derivative right to speech. It is derivative in that it is based on another person's right; and it is passive in that it is based on an autonomy right to hear rather than to speak. Insofar as the corporation is an irreducible source of communication to which the public is entitled to listen, it niakes perfectly good sense to ascribe to the corporation this kind of right. This is essentially the view of corporate speech adopted by the Bellotti Court. ${ }^{32}$ But the Court failed to notice the implications of this characterization in Bellotti as well as in Austin.

The point at which niy analysis departs from that of the Bellotti Court's is when the Court rejected an argument for restricting corporate speech based on the concern that corporate wealth and power may be

31. See supra notes $7-8$ and accompanying text.

32. See First Nat'l Bank v. Bellotti, 435 U.S. 765, 781-83 (1978) (stating that the first amendment fosters not only individual self-expression but also "public access to discussion, debate, and the dissemination of information and ideas," id. at 783). 
used to "drown out other points of view,"33 thus undermining the "State's interest in sustaining the active role of the individual citizen in the electoral process." 34 Instead, the Court invoked Buckley v. Valeo, ${ }^{35}$ in which it had determined that "the concept that governinent may restrict the speech of some elements of our society in order to enhance the relative voice of others is wholly foreign to the First Amendment."36 Crucial to this argunient is the assumption that those "elements of our society" whose speech may not thus be restricted have themselves an original autonomy right to speak. If they do have such a right, then the Court's conclusion is sound; it is fundamental to the nature of autonomy rights that they resist trade-offs. An individual's right to self-expression can no inore be suppressed in the nanie of first amendment concerns than it can be sacrificed to promote any other interests of other individuals.

However, since the Bellotti Court correctly refrained from endowing corporations with active speech rights, the speaker's own autonomy was not at stake. Thus, there is nothing to protect corporate speech against limitations whose purpose is to promote the listeners' first amendment interests, the source froin which the corporation's own rights are derived. This critical difference between an original autonomy free-speech right and a derivative free-speech right was overlooked by the Court. Because the difference and its legal implications are crucial, I will discuss them in somewhat greater detail.

A derivative right is instrumental, whereas an original autonomy right is not. Within the linits set by its scope and weight, an original autonomy right inay not be compromised even for the sake of enhancing the enjoyment of a similar right in others-doing so would be an impermissible act of sacrificing one person for another. In contrast, the entire purpose of a derivative right is to safeguard or enhance the enjoyment of certain rights by others. A derivative right is therefore ineasured-as all instruments are-by its effectiveness. It can always be discarded in favor of better means to attain the saine goals.

The legal implications of characterizing a corporation's right as a derivative right can be best stated in terms of the proper standard of review to which the restrictive legislation should be subjected. In striking down the statute under attack, the Bellotti Court applied the strictest constitutional standard-“"the exacting scrutiny necessitated by a stateimposed restriction of freedom of speech."37 Insisting that corporate speech is a derivative right does not imply that this standard should gen-

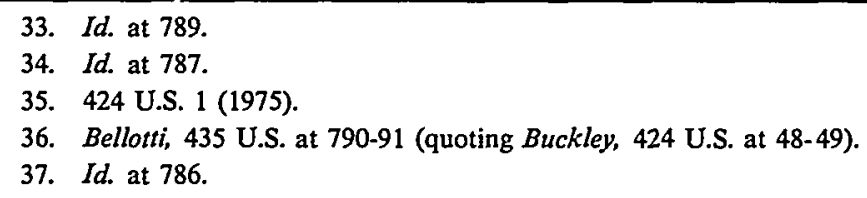


erally be relaxed and replaced by a less exacting one. Instead, it calls for a more complex and discriminating approach that combines two different standards of review. In calibrating the adequate constitutional protection of a derivative right, we should sharply distinguish between "internal" and "external" concerns opposing the right in question.

External concerns are those that justify restricting rights in order to promote interests and values other than those protected by the derivative right itself. Professor Brudney provides a good example of such an external concern. He suggests that because the practice of "[a]llowing capital to be raised on the condition that its contributors perumit management to use it for political purposes . . may increase the cost of capital," an economic reason exists for subjecting corporate political speech to a requirement of unanimous shareholder consent. ${ }^{38}$ This argument, whether sound or not, clearly proposes to curtail speech on behalf of a distinct and separate governmental interest-that is, an interest in the low cost of capital.

But a derivative autonomy speech right is imtended to protect the listener's autonomy interests precisely against such external, nonautonoiny-based threats. If a histener's autonomy interest is to be compromised by external considerations at all, those considerations should at least be "compelling" considerations that satisfy the most exacting constitutional test.

The opposite is true when a derivative right encounters an "internal" concern that justifies curtailing speech in order to protect the same autonomy interests that the derivative right is itself intended to protect. The government inade precisely such an argument in Bellotti when it pointed out that due to the wealth and the size of corporations, "their views may drown out other points of view." 39 Since both the derivative speech right and its proposed curtailment by the state advance the same interest and draw their normative strength froin the same source--the individual listener's ability to form independent and informed judgments based on free access to an unlimited flow of information and ideas-a less exacting standard of review should be applied. An "intermediate review" or a "rational basis" standard would seem to suffice. Considering the indeterminacy of these various standards of review, it is quite difficult to predict how any given piece of legislation would fare under the different standards, although relaxing the standard in the way indicated here would be quite consequential in shaping the constitutional status of corporate and organizational political speech in general.

The preceding discussion is equally applicable, and in this case sup-

38. Brudney, supra note 4 , at 264.

39. Bellotti, 435 U.S. at 789; see also Chevigny, Philosophy of Language and Free Expression, 55 N.Y.U. L. REv. 157, 189-90 (1980) (discussing the same argument). 
ports, the decision in Austin. I shall not repeat it. Instead I will summarize the argument of this section as follows. The traffic in communication may call for a certain degree of regulation to avert congestion that would otherwise be detrimental to the listeners' interests. Such congestion can arise due to disproportionate input by large corporations as well as wealthy individuals. Regulation of this communications traffic may pass constitutional muster when it targets corporations even though it would fail if individual speech was the target. This disparity is a result of the fact that a corporation's right to free speech, like that of any utilitarian organization, is derivative of and parasitic to the listener's interests. In contrast, an individual, in addition to having the same derivative rights as a corporation, is also protected by an original active right to self-expression.

\section{Expressive and Protective Organizations}

Thus far, I have accounted for an organization's right to free speech as arising exclusively from the passive derivative right of a utilitarian orgamization. But this account, appropriately characterizing the speech of business corporations, does not completely describe the reasons for legally protecting other types of organizational speech. In this section, I shall consider another possible normative characterization of organizational speech that implies additional reasons for protecting such speech.

Though organizational speech does not give rise to an original active right to self-expression, the organization may still possess derivative active rights to speech. Legal protection that is extended to such organizations is based on a concern for the individual members' original expressive rights and on the recognition that such organizations aid the exercise of those individual expressive rights. There are two different types of organizations that possess such active derivative speech rights: expressive organizations, which acquire such rights by delegation from their members, and protective organizations, which acquire such rights as adjuncts to their mission of facilitating and protecting their members' speech.

\section{Expressive Organizations}

Many organizations, unlike business corporations, are established for the specific purpose of engaging in speech, which figures prominently among their organizational goals. By joining such organizations, the individual members delegate their active speech rights respecting specific issues to the organization and acquiesce to having their views represented by the organization. Various political associations and trade unions are obvious examples. I will call such organizations expressive organizations.

As an initial matter, the analysis of the notion of "organizational 
speech" in Subsection II. $\mathrm{A}^{40}$ applies to the speech of expressive organizations as well. We intelligibly ascribe a particular statement to the organization-rather than to any individual speakers-precisely because of those organizational variables, structures, and procedures that are interposed between the views and discursive input of any given individual on the one hand and the final organizational communicative product on the other; or because of the "detached speech" that is produced on the organization's behalf by functionaries speaking in their "official" capacity.

Still it makes sense to ascribe expressive value to this organizational performance for the following reason. Individuals jom and manitain their affiliation with expressive organizations because of the organization's commumicative activity and despite the potential disparity between each individual's views and communicative intentions and the organization's speech. The mani reason for this is simple. In the area of the particular orgamization's mission, individuals trade accuracy for volume-in having their views expressed by the organization, individuals know that these views will gam greatly im audibility, thougli they may also be distorted in the process. Given this implicit and often advantageous bargain, it makes good sense to ascribe derivative expressive value, as discussed in Section $\mathrm{I},{ }^{41}$ to the organization's speecli. The individuals can be said to have delegated to the organization their expressive interests in a certain area as the best, and indeed preferred, approximation of an authentic, individual performance.

Without getting into much doctrinal detail, it is worth mentioning that the present argument generally comports with and, if sound, supports the Supreme Court's position in Federal Election Commission v. Massachusetts Citizens for Life, Inc., ${ }^{42}$ in which the Court articulated criteria for exempting an organization (whether or not it lias a corporate form) from the kind of speech regulation that would be permissible with regard to an ordinary business corporation. ${ }^{43}$ Still, characterizmg the organization's active speech right as a derivative right has certain imphcations that I think deviate from the Court's understanding of the issue.

My present point resembles the more general critique of legal protections for organizations' speech in Section II.C.44 There I warned against the fallacy of immediately endowing organizations with full first amendment protections once we have ascribed speech to them. Instead, in the case of utilitarian organizations that we discussed, such speecli

40. See supra notes $9-20$ and accompanying text.

41. See supra notes 7-8 and accompanying text.

42. 479 U.S. 238 (1986).

43. Id. at 263-65.

44. See supra notes 31-39 and accompanying text. 
need only be protected as a passive derivative right, without the additional protections due to an active right to self-expression. Legal protection for expressive organizations' speech presents the danger of a similar, though somewhat less acute, error. Recognizing an active right to speak in an expressive organization does not automatically and necessarily endow it with unqualified first amendment protection. There is an important difference between an original and a derivative right to speak. Original speech, by the individual speaker, has first amendment value in and of itself: It is by itself the embodiment of the values of self-expression and self-realization that are at the core of the amendment. The organization's speech, by contrast, derives its value from its relationship, its proximity, to such original speech. And this relationship-this proximity-is a contingent matter.

The potential for distortion of communication that inheres in bureaucratic structures accentuates the contingent nature of organizational speech. I will not elaborate on the subject here; suffice it to mention that "the iron law of oligarchy" 45 and the various processes of "goal displacement" 46 work to widen the ever-present gap between the individual members and their organizationally mediated self-expression. Thus, insofar as the constitutional protection of expressive organizations' speech depends on the "delegation" relationship, such protection is justified only as long as the orgamization genuinely fulfills the conditions and purposes of the delegation. The internal structure and the decisioninaking processes of expressive organizations thus become, in principle, matters of public, indeed constitutional, concern. A bureaucratic strncture that has become sufficiently entrenched and fossilized so as to lose all connection with the meinbers on whose behalf it purports to speak will surely have substantively lost its claim to expressive value. The familiar specter of the membership organization without any menbers is the limiting case. ${ }^{47}$

45. See R. Michels, Political Parties: A Sociological Study of the Oligarchical Tendencies of Modern Democracies, 377-92, 401 (E. \& C. Paul trans. 1915) (arguing, inter alia, that an organization, once created, "creates for itself . . . interests peculiar to itself," $i d$. at 389).

46. "Goal displacement" occurs when an organization

substitutes for its legitimate goal some other goal for which it was not created, for which resources were not allocated to it, and which it is not known to serve.

The mildest and most common form of displacement is the process by which an organization reverses the priority between its goals and means in a way that makes the means a goal and the goals a means. The most common means so displaced is the organization itself. Organizations are instruments; they are created to serve one or more specific goals. But in the process of forming them, of granting them resources, and of recruiting personnel, interest groups are formed which are frequently concerned more with preserving and building up the organization itself than in helping it to serve its initial purpose. These interest groups use the organizational goals as means to recruit funds, to obtain tax exemptions or status in the community, in short, as means to their own goals.

A. ETzioni, Modern ORganizations 10 (1964).

47. See, e.g., J. Wilson, Political Organizations 211 (1973) (claiming that for an 


\section{Protective Organizations}

Similar considerations apply to the other way in which organizations can acquire active derivative rights under the first amendment. An organization can possess such active derivative rights insofar as it protects or enhances an individual's self-expression and to the extent that the satisfaction of certain organizational claims is necessary to the performance of this function. I will call an organization whose goal is to protect or facilitate individual self-expression a protective organization. Of course the two designations-protective and expressive organizationare not mutually exclusive. Indeed, $N A A C P$ v. Alabama ex rel. Patterson, ${ }^{48}$ my first case example, is amenable to analysis in both of these terms.

In NAACP v. Alabama, the National Association for the Advancement of Colored People (NAACP) objected to a state-compelled disclosure of its membership list. ${ }^{49}$ In determining that the association "is but the inedium through which its imdividual members seek to make more effective the expression of their own views,"s0 the Supreme Court in effect recognized the NAACP as an expressive organization. However, given the specific facts of the case, it is perhaps more accurate and illuminating to view the NAACP as a protective organization. By securing its members' anonymity, the association protected their individual right to freedom of expression from the likely harassments and intimidations characteristic of the poitical atmosplere of the time. ${ }^{51}$ Under such circumstances, it seens eminently plausible to maintain that the organization in question has a riglit, derivative from the right to self-expression of its inembers, to maintain the secrecy of its relevant records. ${ }^{52}$

The university serves as a somewhat different example of a protective organization, illustratimg botli the operation of an active derivative speech right as well as its limitations. The cliaracterization of the university as a protective organization is based in the first place on the view that academic freedom is an instance of the more general right to free self-

increasing number of associations, "'members' exist only as an historical artifact, as symbols of "private' legitimacy, or as grounds for claiming a representational function").

48. 357 U.S. 449 (1958).

49. Id. at 449 .

50. Id. at 459. Based on this view, the Court recognized the NAACP's standing to raise its members' rights. $I d$.

51. Id. at $462-63$ (noting that disclosing the identity of the NAACP's members would expose them to "public hostility").

52. The fact that the NAACP enlisted the first amendment in protection of its right to remain silent (that is, to refrain from disclosing its membership lists), rather than in defense of any speech of its own, does not significantly bear on my analysis. This fact only suggests that a derivative first amendment right need not concern only organizational speech but may protect other organizational activities and interests, provided that their protection is in the service of the members' selfexpression. 
expression. ${ }^{53} \mathrm{By}$ academic freedom I mean, roughly, the freedom to engage in the creation and commumication of ideas, scientific knowledge, and the like. Secondly, the promotion and the protection of academic freedom is one of the university's central goals. ${ }^{54}$ In this context, the university provides the needed aniemities and the sheltered and congenial environment necessary for a meaningful exercise of that right. For example, a university may imstitute a decisionmaking process that allocates among its faculty resources needed for their contemplation and research without at the sane time imposing on them restrictions that may interfere with their academic freedom. This decisionmaking process is a valuable asset fron the point of view of each professor's academic freedom.

A certain degree of autonomy and independence of this decisionmaking process niay in turn be necessary for its successful and smooth functioning. To the extent that this is so, the university can be said to possess an autonomy right, which amounts to a right to the independence of its decisionnaking process from intrusive interventions. This right is obviously of a derivative kind: It is based entirely on the concern for the individual professor's academic freedom-his or her right to free speech. More generally, the university's derivative autonony rights are rights that are necessary for, or conducive to, promoting and protecting academic freedom. ${ }^{55}$

The uurversity's active derivative right shares, to a certain extent, the normative status of the original right to academic freedom from which it is derived. The concern for protecting the professor's right to academic freedom also justifies extending a similar protection to those liberties and immunities of the university that are deemed necessary for assuring researchers such protection. Specifically, if we believe that utilitarian considerations cannot, as a general rule, override a professor's right to academic freedom, we should also maintain that the rights of the university necessary for the protection of the professor's academic freedonı nust be similarly immune to adverse utilitarian considerations.

However, determining in general the scope of an organization's

53. Academic freedom has in fact been recognized as a first amendment right. See Keyishian v. Board of Regents, 385 U.S. 589, 603 (1967) (stating that academic freedom is a "special concern of the First Amendment, which does not tolerate laws that cast a pall of orthodoxy over the classroom"); see also T. EMERSON, THE SYSTEM OF FREEDOM OF EXPRESSION 613-14 (1970) (discussing the first amendment as a source for academic freedom).

54. See Gross, Universities as Organizations: A Research Approach, 33 AM. Soc. REV. 518, 529-30 (1968) (finding in a poll of university administrators and faculty members that academic freedom is, and ought to be, first among universities' goals).

55. But $c f$. University of Pa. v. Equal Employment Opportunity Comm'n, $110 \mathrm{~S}$. Ct. 577 (1990). The Supreme Court upheld a subpoena requiring the university to release confidential peer review materials regarding alleged sex-and race-based discrimination in the tenure review process of a former faculty member. The Court considered the injury to academic freedom to be "remote," "attenuated," and "speeulative," id. at 588, and refused "to recognize an expanded right of academic freedom to protect confidential peer review materials from disclosure," $i d$. at 587. 
derivative right is not a simple matter. No great difficulties would arise if the organization were meticulously optimizing the single goal of protecting the relevant original right. If this were the case, the organization's derivative right would be coextensive with its entire activity. Any successful claim to "injury" made by such an orgamization (that is, any successful claim that an event constitutes an impediment to the achievement of its goal) would be a transgression of the organization's derivative right. So, to continue our example, if the umiversity were solely committed to protecting the academic freedom of its faculty, the university's clain to autonony would be fully supported by the faculty's underlying original right. But as is typical of most large organizations, the university pursues a variety of goals. Some of then are unrelated to the professors' (or anyone else's) academic freedom. In that case, the university, like any other organization, may try to rely on its derivative rights im the service of any of those other goals, thereby trying to extend the derivative right beyond its legitimate scope as defined by the underlying original right.

Goal displacement ${ }^{56}$ is likely to contribute to the discrepancy between the organizational derivative right and actual organizational claims. For example, subunits within the organization may engage im activities geared towards the accomphishment of their own subgoals in a way and to an extent that do not necessarily comport with the achievement of the overall organizational goal. These subunits are likely to invoke the organization's rights in protection of their goals, even though the particular activities concerned do not in fact contribute to, and may even hinder, the individual, original rights from which the orgamizational right is derived. The canıus police, for exaniple, and otler disciplinary authorities may pursue their departmental subgoal of preserving "law and order" zealously and single-mindedly in ways that are sonetimes detrimental rather than conducive to the promotion of academic freedom. And yet the umiversity is likely to invoke its institutional autonomy, expressed in the idiom of academic freedom, as an argunent against judicial review and possible interference with a university disciplinary proceeding that resulted, say, in the expulsion of a student who had participated in a denıonstration on campus.

This example and these observations are simply meant to underline the caution with which organizational active derivative speech rights nuust be recognized and apphed. The willingness to immunize certain organizational claims from conflicting utilitarian considerations must be coupled witl an awareness of the potential for abuse inherent in suclt immunity. The multiplicity of organizational goals, the plienomenon of goal displacement, as well as organizations' tendency toward self-aggran-

56. See supra note 46 . 
dizement, ${ }^{57}$ all complicate the task of maintaining full correspondence between an organization's derivative right and the underlying individual autonomy right.

I have described in this section two kinds of organizations, characterized by reference to their respective goals, that can acquire active derivative speech rights. The present discussion should hopefully further clarify the significance, for purposes of first amendinent analysis, that I earlier ascribed to cliaracterizing business corporations as utilitarian organizations. By contrast to the organizations discussed in this section, utilitarian organizations ordinarily perform neither an expressive nor a protective function. We can thus conclude that the speecl of utilitarian organizations is devoid of expressive value and its protection depends exclusively on the listeners' interests served by it.

\section{III}

\section{COMMUNAL SPEECH}

I have so far determined that utilitarian organizations have passive derivative speech rights, while expressive and protective organizations possess in addition active derivative speech riglits. In botl cases I have maintained that organizations do not bear original rights to self-expression. However, our discussion has not yet covered all varieties of collective speecl. In the present section I want to examine a form of collective speecl tliat can make a claim to original expressive status consistent with the view of speech as an autonomy right ${ }^{58}$-communal speech. Recognizing and examining this brand of speecl is important in and of itself; but it will also help further clarify, by way of contrast, the nature of organizational speech.

\section{A. Role-Distance and the Distinction between Community and Organization}

There are many different ways in wlich community and organization can be distinguislied, but for the purpose of niy arguinent drawing the distinction in terms of the concept of role-distance will be best. ${ }^{59}$ As will be recalled, by generalizing from a paradigmatic organizational role-that of an AT\&T operator-we were able to ascertain and elaborate on the detached nature of organizational roles. I will presently follow a similar strategy by focusing on a role within a collectivity-the

57. On the tendency of organizations toward expansion and self-aggrandizement for systemic reasons, see C. Barnard, The Functions of the Executive 159 (1966); A. Downs, Inside BUREAUCRACY 16-18 (1967).

58. See supra notes $7-8$ and accompanying text.

59. The classical formulation of the distinction between community and organization is in $F$. TÖNNIES, COMMUNITY AND SOCIETY (C. Loomis trans. 1957) (describing the dichotomy between "organic life" (Gemeinschaft) and "imaginary and mechanical structure" (Gesellschaft)). 
family - that in its ideal form I take to be the paradigm of community. Consider then the role of a parent and compare it to that of the AT\&T operator. Unlike the operator's case, the parental role is quintessentially nondetached. The imperatives that guide me in discharging my role as father are in an important sense internal to me. I simply do what I think best in a certain regard, for example in matters that pertain to my child's education or behavior or welfare. In sharp contrast to the operator's case, inducement and compulsion are neither necessary nor appropriate in this case. Consequently, we can say that in discharging my duties as father, my conduct is fully autonomous. This is not because I can treat my child with unfettered discretion, let alone arbitrarily. Quite the contrary, the demands of my role as father often are circumscribed quite narrowly, mandating a very specific attitude or course of action as the appropriate one. Still, these imperatives do not compromise my autonomy but rather express it, since they follow from me; they shape or constitute an aspect of my own identity, namely that of parent.

Once agam, the normative aspect of role-distance should be emphasized. Many a parent will on different occasions feel detached from their parental role. But enacting a parental role at arm's length, so to speak, violates a pervasive norm regarding the appropriate relationship of parenthood to the self. Just as an overly zealous telephone operator who identifies excessively with his role can be accused, as we said, of "bad faith," 60 so a detached parent suffers from alienation. In the conceptual scheme that I propose, ahenation is inappropriate role-distance-it is distance from what is supposed to be one's nondetached role.

Generalizing from these observations concerning parenthood and the family, we can define a community in terms of the concept of roledistance as a social union of nondetached roles. Thus, a community is a collectivity whose roles do not allow their holders to maintain a distance from those roles. What are the implications of this conception of community for the constitutional protection of its speech?

\section{B. Communal Speech and Role-Distance}

When we discussed organizational speech, we saw that detached speech can be produced by a specific individual and yet involve no selfexpression nor implicate that individual's autonomy. The opposite is the case in the communal context: Speech uttered in one's communal roleI will call it nondetached speech-involves both autonomy and selfexpression. To see this, consider the following example. Suppose that someone had just helped my four-year-old daughter to cross the street as

60. See supra note 19 and accompanying text. 
I happen to walk by. Being in general a polite fellow, I say to the benefactor something like "Thank you for helping my daughter."

The first thing to notice about this situation is this: My expression of gratitude, just like the similar utterance made by the telephone operator, is strictly a matter of performing a role. After all, the benefactor has not rendered any help directly to me. It is only by virtue of my parental role, and as an aspect of it, that it is appropriate and necessary that I thank the helper under these circumstances. But it is equally important to notice that unlike the operator's case, once I have ascertained that it is incumbent upon a father to express gratitude under these circumstances, no further question about motivation - that is, why I express gratitudearises. It is because I identify with my role as a father, and through this role also with the collective entity (my family), that I experience the service to my daughter as rendered to me. Thus my motivation to perform the utterance is already provided for (though it is not invariably guaranteed) by my general tendency to be a pohte person: My being a father is simply the aspect of my personal identity that pertains to the situation at hand.

These differences in role-distance and motivation create and are reflected in a siguificant contrast in the sincerity of the operator's and the parent's speech acts. We have observed the oddity that would result from the operator's express profession of sincerity when he recites the "Thank you" refrain to a customer. ${ }^{61}$ No corresponding problem arises in the case of parental and, more generally, communal speech. An important aspect or consequence of the fact that I identify with my fatherly role is that by making the appropriate utterance-"Thank you for helping my daughter"-I actually express my gratitude. In doing so, I abide by the condition of sincerity, which in this case simply means that my utterance truthfully conveys my sense of gratitude. This is evidenced by the linguistic propriety of my augmenting my expression of gratitude with the "and I really mean it" that would be out of place for the operator.

The fact that the criterion of sincerity does not apply to the operator's speech served for us as a revealing sign of the operator's role-distance, and it helped explain why we do not consider the operator's detached communicative performance as a matter of his own self-expression. The parent's example permits us now to draw the complementary conclusion. When the role is a nondetached one, as it is for members of a community-such as parents in a family - the distinction between individual and collective speech is effaced. The expression is a collective utterance; I perform it only because I occupy this communal role and because my role has provided the imperative for me to do so. But at the

61. See supra note 18 and accompanying text. 
same time, the utterance is also an individual performance, internally motivated and marked by sincerity, for the simple reason that my membership in the collective entity is an aspect of my individual identity.

\section{Communal Speech and Identification}

As I tried to show in the case of organizational communication, speech can be ascribed to a collective entity not just on the basis of an utterance by a specific role-bearer but also as the composite product of an undifferentiated, collective activity. Here too, the communal picture is radically different from the organizational one. I can best make the point with the help of a familiar analogy: the orchestra or the choir. A number of features of these ensembles bear on my argument.

First, observe that each individual player's (or singer's) performance is strictly circumscribed by "rules" (the score) that attach to his or her role (for example, as second string). This fact does not however detract from the expressive value of the performance. Secondly, each imdividual's contribution is in itself fragmentary and often musically (or in the case of the choir also limguistically) unintelligible. The expressive value of these performances cannot, therefore, be in the individual renderings taken separately. Rather, the medium of self-expression in these cases is the collective production-the performance of the musical piece taken as a whole. And yet this "global" or collective production is a vehicle for the self-expression of each of the players. The reason that the orchestra's performance is a matter of each player's self-expression lies in identification. Each player fully identifies with his or her role and, through it, with the collectivity, the orchestra, within which the role is performed. The result again is an effacement of the distinction between the collective production and individual self-expression. The collective production is in this case individual self-expression. ${ }^{62}$

Moreover, as these examples suggest, in the case of communal speech the communal context is an essential part of the meaning of the communication-it is part of the message. Communal speech gives expression to that aspect of each member's identity that is bound up with the community. Trying to extract the speech from its communal context will inevitably destroy its distinctive meaning and value as an expression and realization of an important aspect of persons' identities.

The contrast with the expressive organization is instructive. In that case, delegation involves a trade-off between the accuracy of representation and the volume of collective speech. Communal speech implies no such trade-off because it lacks the gap-ineliminable in the organizational setting-between the individual participants and the collective

62. On the "situated" self, for whom communal membership is an aspect of identity, see, e.g., M. SANDEL, LibERAliSM AND THE IIMITS OF JUSTICE 19-21, and passim (1982). 
production. ${ }^{63}$ We have also seen that the communal context is itself a constituent of the meaning and expressive value of communal speech. Not so in the case of the organization: Even the expressive organization plays a purely instrumental and potentially distorting role relative to the messages it conveys. Insofar as communicative content is concerned, the expressive organzation is in principle dispensable. Silencing its speech would still allow its individual members to express their views and opinions, albeit with a loss of amplitude-sotto voce as it were.

Both the phenomenology and the normative status of identification require much more detailed analysis than I have given to them here. ${ }^{64}$ Still, I hope that I have said enough to point to a category of collective speech-I call it communal-in which the distinction between collective speech and mdividual self-expression collapses. In such cases, it makes perfectly good sense to treat the collective performance-the communal expression - as an original autonomy right, and thus to extend to such speech the full constitutional protection entailed by the values of selfexpression and self-realization that are at the core of the first amendment.

\section{IV}

\section{GOVERNMENT SPEECH}

My analysis of collective speech would not be complete without mentioning speech by the most prominent of collective entities-the state; but the discussion could not be completed if I attempted here a comprehensive survey of this notorious mine field. My way out of this dilemma is to place heavy reliance on the following disclaimer. The intention of this section is only to outline, in a cursory and tentative fashion, the possible apphication of the theoretical framework that I have so far developed to a selected number of issues associated with what is loosely and somewhat imprecisely referred to as "government speech."65

63. Different theories of representation may be distinguished by whether or not they admit the existence of a "gap" between the represented and the representative. As Hanna Pitkin points out, symbolic representation does not allow for such a gap. Hence, there is no term "missymbolizing" to correspond to "misrepresentation." See H. Pitkin, The Concept of RePresentation 99 (1972). However, there are faseist overtones in a theory of representation that emphasizes the alignment between the leader's will and that of the people. Id. at 107-08.

64. On the relationship between personal identity and "identification," see H. FRANKFURT, Identification and Externality, and Identification and Wholeheartedness, in THE IMPORTANCE OF What We Care About: Philosophical Essays 58, 159 (1988).

65. The most comprehensive study of this subject to date is M. YUDOF, WHEN GOVERNMENT SPEAKS: Politics, LAW, AND GOVERNMENT EXPREssion IN AMERICA (1983). 


\section{A. Conceptions of the State and Government Speech}

The looseness and imprecision of the term "government speech," under which expressions by the state's various institutions are commonly discussed, directly relate to the distinction between commumity and organization. Our vision of the state, and our attitude toward it, oscillate sharply between the two poles marked by the terms "community" and "organization" as contrasted in the preceding section. Considering the state in terms of the proposed model allows us to get a clearer view of the state's dual nature and enables us to refine the legal treatment of the various communications commonly subsumed under "government speech."

We often think of the state as a vast bureaucracy or, perhaps more accurately, as a conglomerate of bureaucracies-impersonal, goal-oriented, and self-perpetuating. Such entities inspire distance. We tend to experience our interactions with them, in whatever role or capacity, as remote and external. The state is also the quintessential coercive collectivity. It often addresses us by means of threats, backed by the most brutal force. Reliance on such external motivation for compliance with the state's demands both fosters and reflects distance. It is at once a recognition and a consolidation of the fact that one's actual contmued assent is not required or expected as a condition of one's playing a role in the collective enterprise. When we contemplate the state under both of these characteristics-bureaucracy and coercion-we envision an organization: a collectivity whose claims are external to us and from whose clutches we flee by maintaining a distance between our engagements with it, on the one hand, and our true selves, on the other. ${ }^{66}$

But this is not the only way we can think about the state. It is not just a giant bureaucracy that acts by coercion. To be an American, for exanuple, is not only to stand in a certain relationship to the American government and be subject to its coercive threats. It also means to share important bonds, such as of tradition, history, or language, with a vast number of other people. "American" is accordingly a summary reference to a composite role or, perhaps even more accurately, a cluster of roles, many of which are nondetached, inextricable constituents of an American's innermost identity. The state is therefore also the social union of these nondetached roles and, to that extent, a community.

The inadequacy of designating as "government speech" all communication emanating from the state should now be clear. The term "government" tends to connote the bureaucratic and organizational aspect of the state. If one thinks of the state's expressive activity in terms of gov-

66. For a similar conception of the state and its relation to the self, see Gabel, The Phenomenology of Rights-Consciousness and the Pact of the Withdrawn Selves, 62 TEX. L. REv. 1563 (1984). 
ernment institutions, it is natural to maintain, as a matter of course, that "communications emanating from such institutions do not vindicate individual self-expression and dignity." 67 In other words, the characterization of communications by the state as "government speech" creates a bias against recognizing such communications as possessing original expressive value. Conceived as an organization, government cannot indeed be seen plausibly as the medium for individual self-expression associated with the values of autonomy and self-realization that give rise to original speech rights. However, such organizational speech need not encompass all of the state's expressive activity. Insofar as we consider the state's communal aspect, its communications may exhibit the characteristics and assume the normative status of collective self-expression that do give rise to original active speech rights.

The term "government speech" is inadequate in another way. Government is here referred to in the singnlar. Such usage conjures up the iniage of government as one manimoth bureaucracy that speaks with a single-and most likely deafening - voice. This characterization understates the fragmentation of modern government into numerous units and entities, which each enjoy various degrees of independence and often feud with one another. The same observation applies to the conimunal conception of the state as well. Government speech need not enianate from the state (for example, the United States of America) conceived of as a single, unified community, but rather can be the product of a myriad of entities of vastly varying structure and size, related in different ways and with different degrees of looseness or tightness to the more inclusive entity. Consequently, a wholesale denial that governnent speech can be the exercise of a communal original right to self-expression is more than to deny the communal aspect of the state as a whole or to maintain that the conimunal aspect cannot be expressed through the state's political institutions. Rather, given the multiplicity and variety of entities subsumed under the designation "state" (or "government"), this negative position would also apply to, for example, each and every municipality, no matter how small, how homogeneous, and how closely knit it may be.

Both the duality of the state and its fragmentation open up the possibility that the communications by various entities-for example, the United States, Nevada, Los Angeles, or the Ainish comnunity-may be viewed as the exercise of original active speech rights. But opening up a possibility is not the same as realizing it. I have not affirmatively argued that any particular kind of speech emanating from any one of the entities I have just listed qualifies as communal self-expression. Indeed, I have not even articulated the conditions or the criteria that would permit us to recognize the phenomenon when we see it, though I have touched upon

67. M. YUdoF, supra note 65 , at 43. 
it in the context of individuals' identification with the source of allegedly communal speech. In order to categorize a particular commumication as communal self-expression, we need criteria for classifying the relevant entity as a community as well as standards for ascertaiming whether the communication in question was produced in such a way or by such a person that it can truly constitute the community's self-expression. However, in line with the modest ambitions of this part of the Article, I will not attempt an elaboration of such criteria here. ${ }^{68}$

\section{B. Varieties of Government Speech}

\section{Government Speech as Communal Speech}

To ignore the possibility that government speech might have expressive value with underlying original active speech rights would severely cripple the debate on government speech. This is, for example, what happens when advocates of certain forms of government speecl, for example that of municipalities, equate such speech with corporate communications. ${ }^{69}$ The rationale for drawing the analogy is of course to draw support for municipal commumications from the Supreme Court's recognition of corporate free speech in cases such as Bellotti. ${ }^{70}$ But drawing this analogy gives up at the outset the possibility of making out a stronger case for a more robust right by exploring the municipality's cominunal aspects and by investigatimg the relationship between the speech in question and individual self-expression. ${ }^{71}$

Whether we classify a particular communication as communal selfexpression significantly affects the strength of the various arguments opposing the idea of protected government speech. Three of those arguinents are particularly relevant here.

The first concerns the rights of dissenting imdividuals. After all, doesn't the community use their money and purport to speak on their behalf, thus coercing them into expressions and violating their freedom of speech? One simple answer to this objection is that there need not

68. For more on this point, see Professor Tribe's discussion of Village of Belle Terre v. Boraas, 416 U.S. 1 (1974). In Belle Terre the Court upheld an ordinance by which some two hundred families sought to preserve the character of their town by excluding, inter alia, groups of three or more persons unrelated by blood or marriage sharing the same household. Tribe suggests that assessing the associational rights of Belle Terre may call for an ascertainment of its genuine "communal" nature: "Belle Terre may not be a real 'community' or 'association' at all but simply a collection of persons . . . because it has no organic life as a center of communal perceptions and common activities." L. TRIBE, AMERICAN CONSTITUTIONAL. LAW § 15-18, at 979 (1978).

69. See, e.g., Note, The Constitutionality of Municipal Advocacy in Statewide Referendum Campaigns, 93 HARV. L. REV. 535 (1980).

70. 435 U.S. 765 (1978).

71. For a sustained normative argument in favor of a more communal conception of municipalities than we presently recognize, see Frug, The City as a Legal Concept, 93 HARV. L. REV. 1057 (1980). 
always be such a dissenting group within a community. Indeed, one may hold the view that virtual unanimity is a condition for characterizing speech as communal. Shouldn't such communication be inmune to abridgment by other state agencies? ${ }^{72}$ Suppose, however, that a dissenting group does exist. Is it now legitimate to curtail the offending communication? If the very presence of such a dissenting group does not deprive the expression in question of its communal character, the proper solution to the conflict would not be the abridgment of the proposed commumication. Given the communal nature of the communication, such an action would stifle genuine self-expression. A more attractive reinedy under these assuinptions would seem to be one that aims to secure for the dissent-perhaps by the allocation of adequate funds to it-an appropriate opportunity to disassociate itself from the community's inessage and voice its own version. Silencing coinmunal expression altogether should only be considered when this other option is not available.

The second conimon argument against protecting government speech arises from the fear of state propaganda. ${ }^{73}$ Again, the topic is large, and I will only comment on it insofar as the categories I have been using can clarify the current debate. There is a concern that government speech will saturate the inarketplace of ideas and drown out other voices because the government has access to and control over immense communicative resources. Controlling government speech would thus appear to be inerely a inatter of regulating the communications traffic in the listeners' interest. But as I have previously remarked, ${ }^{74}$ such a policy is least compelling when it involves the suppression of expressive speech, or, in my terminology, the curtailment of someone's original active right to speak. Although most governinent speech does not involve such a right, government speech that is a form of communal self-expression does. The argument based on the fear of propaganda is accordingly weakest in these cases. ${ }^{75}$

Finally, the suppression of governmental-specifically municipalspeech has been justified on the ground that such suppression does not have siguificant costs in terms of freedom of expression. After all, it is

72. An affirmative answer is suggested by Anderson v. City of Boston, in which the court mentions the possibility that "the Commonwealth has no right to restrict [advocacy by a municipality on a referendum question] where there is no opposition from any affected citizen." 376 Mass. 178, 196, 380 N.E.2d 628, 639 (1978), appeal dismissed, 439 U.S. 1060 (1979).

73. M. Yudof, supra note $65,20-37$ and passim.

74. See supra notes $33-36$ and accompanying text.

75. The observation that government is fragmented is equally significant here. Thus, saturation of the marketplace of ideas is least plausible when the speaker in question is a small community, especially so when its voice must compete with other organizational speakers, for example, large corporations, which may be active in the same locality and whose communications do enjoy first amendment protection under Bellotti. 
argued, municipal officials can still express their views in their "private" capacity and "[s]o long as the First Amendment rights of such officials are preserved, the point of view of those who perceive a particular political outconie as niost desirable for the nunicipality will be expressed."76

I have already commented in general on the fallacy of such a reductionist "solution." If the official's role is a nondetached one, then there is simply no distinction between the speaker's official role and her private capacity. ${ }^{77}$ Every expression by that speaker within the role's domain is at once both official and private. ${ }^{78}$ In contrast, if the official performs a detached role, the assurance that no loss of communicative content will result front confining his speech to his private capacity is false too. As I argued earlier, there is no reason to beheve that a person would be motivated or inclined to engage in the same speech activity outside his role as he would in performing his role. ${ }^{79}$

\section{Government Speech as Organizational Speech}

When we consider the state in its organizational guise, the same categories of organizational speech that I have distinguished apply: Government entities can also nianifest theniselves as expressive, protective, or utilitarian organizations and be subject to the consequent normative considerations. As an illustration, consider the case of Town of Huntington v. New York State Drug Abuse Control Commission. ${ }^{80}$ There, the town objected to a New York State Drug Abuse Control Commission directive requiring the town to compile forms on patients in its drug abuse prograin in order to retain funding for the program. The town claimed that conpliance with this requirement would violate the individuals' privacy rights. ${ }^{81}$ The analogy to $N A A C P$ v. Alabama ${ }^{82}$ is clear. Just as the NAACP's refusal to disclose its members' identity protected their first amendment rights, thus creating an active derivative speech right in the association, the nunicipality's refusal in Town of Huntington to divulge information regarding the drug addicts protected the latter's right to privacy. The Town of Huntington in this context performed the role of a

76. M. YUDOF, supra note 65 , at $49-50$.

77. Of course, by labeling the speaker an "official" we have for the most part begged the real question and predetermined the conclusion. "Official" connotes a bureaucratic structure and thus locates the speaker in a context in which the distance between "official role" and "private capacity" is already inplied. But think instead of a different designation for a coinununity representativespiritual leader perhaps, or priest, or sage. These terms do not allow such an easy separation between role and person as the term "official" does.

78. See supra notes $61-64$ and accompanying text.

79. See supra notes $16-20$ and accompanying text.

80. 84 Misc. $2 d$ 138, 373 N.Y.S.2d 728 (N.Y. Sup. Ct. 1975).

81. Id. at 145,373 N.Y.S.2d at 736 . The town also raised arguinents based on the fourth and fourteenth alnendinents. Id. at 147-48, 373 N.Y.S.2d at 738-39.

82. 357 U.S. 449 (1958). 
protective organization, and should thus have been able to assert derivative rights based on the individual original rights thereby protected. ${ }^{83}$ Though the substantive rights in question in this case were not speech rights, nothing of significance would have changed in the analysis if they were. ${ }^{84}$

Perhaps most often, however, "government speech" is performed by what are best seen as utilitarian governmental entities-those agencies charged with proinoting various aspects of society's welfare. Much of the discussion of "governinent speech" proceeds, it seems to me, on the tacit assumption that all government commumications belong in this category and that the only individual speech rights at stake are listeners' rights. Such an assuinption need not always be true. But when it is, the analysis of the relevant government entity's speech should proceed along the same lines as the analysis of the speech of utilitarian organizations, as discussed in Section II.C. ${ }^{85}$

The divergent normative iinphications of communal speech and the various forms of organizational speech underscore the significance of how particular collective entities are classified. But as the dual nature of the state and its fragmentation into plurahistic entities suggest, we should not expect to find a single, umform type of governnient speech in a field that consists of a inultitude of heterogenous and vastly differing forms of government entities. Just as soine communications in this area may be best understood in terms of cominunal self-expression, others niay be better interpreted as the speech of expressive organizations to which the articulation and dissemination of a particular constituency's beliefs or opinions has been delegated, as the speech of protective organizations that protect their meinbers' active speech rights, or as the speech of utilitarian organizations furthering the welfare of society as a whole.

\section{Which Entity Speaks?}

The multitude and complexity of the existing types of governinent entities suggest implications that extend beyond a mere conplication of the analysis of governnent speech. The problem is not just the multiplicity of categories that we inust choose among in order to characterize

83. The court held that the town had standing to assert the rights of the individual participants in the program. See Town of Huntington, 84 Misc. 2d at 142, 373 N.Y.S.2d at 733-34.

84. In fact the Town of Huntington court cites Gibson v. Florida Legislative Investigation Committee, 372 U.S. 539 (1962), which like NAACP v. Alabama concerned the NAACP's right to preserve the secrecy of its membership as a way to protect the members' freedom of speech. See Town of Huntington, 84 Misc. 2d at 147, 373 N.Y.S.2d at 738. But cf. Whalen v. Roe, 429 U.S. 589 (1977) (upholding as constitutional a procedure by which the State of New York could record, in a centralized computer file, the names and addresses of persons who obtain, pursuant to a doctor's prescription, certain drugs for which both a lawful and an unlawful market exist).

85. See supra notes 31-39 and accompanying text. 
correctly the communications of a particular state entity. The very contours of the entity at issue are often blurred and controverted. Any attempt to ascribe a particular communication to a subdivision of the state, and to confine our analysis to that subdivision, must be precarious simce the ascription is open to counterclaims based on a more unitary or a more pluralistic view of the state.

Motion along the unity-plurality continuum in analyzing government speech constitutes more than just a choice ainong various possible conceptualizations or descriptions of the state or a selection of the inost suitable level of generality or particularity for the normative purpose at hand. Simce at stake is the boundary and the nature of a social entity, and since people's attitudes and understandings are constitutive of the boundary and the nature of such an entity, the controversy presents an "ontological" disagreement. The disputants do not simply disagree about fixing the most adequate unit of analysis; rather, their disagreeinent reveals that no such single entity exists. The source of the disagreement may be conflicting clusters of beliefs and attitudes that are the very constituents of differmg collective units to which the disputing parties relate.

Thus, for example, a city council's proposed resolution condemning the insensitivity of large corporations to the phight of laid-off workers can be for some the apt expression of a communal sentiment, provoked perhaps by a recent incident that occurred in the city. The city council's speecli directly expresses their own frustrations and resentments. Others may perceive the council's proposed resolution in inore detached, organizational terms, approving of the cominunication or acquiescing in it because they view themselves as having delegated to the council expression as well as action on inatters such as these. Still others would, in effect, deny the council both original (communal) and derivative (delegated) speech rights. They could do so, for exanple, by invoking their national identity, argumg that only those who can speak on behalf of the country as a whole-a branch of the federal government, perhaps-are qualified to make pronouncements in their name in matters of social justice. $^{86}$ For these individuals, city council members are but relatively lowlevel functionaries in the state's comprehensive hierarchy and should not presume to enjoy or exercise liberties that are not derived from that

86. Compare Justice Burke's view that "[b]oards of supervisors and city councilmen are not 'representatives of local communities' on matters outside the scope of county and municipal affairs and certainly are not authorized in any representative capacity to express the will of the people on matters of national policy." Farley v. Healey, 67 Cal. 2d 325, 333, 431 P.2d 650, 656, 62 Cal. Rptr. 26, 32 (1967) (Burke, J., dissenting), with the view of Chief Justice Traynor: "As representatives of local communities, boards of supervisors and city councils have traditionally made declarations of policy on matters of concern to the community whether or not they had power to effectuate such declarations by binding legislation." Id. at 328, 431 P.2d at 652, 62 Cal. Rptr. at 28. 
inclusive structure. ${ }^{87}$

Now my point is that these conflicting perceptions of the proposed communication can, in principle, all be valid simultaneously. They express incommensurate but equally tenable social worlds. The social world inhabited by those who find an indispensable outlet of personal frustration in the council's proclamation contains an entity-the local commuinty-tliat is missing from the world inliabited by those whose primary identification in the present context is with the country as a whole and for whom the locality lias purely instrumental significance. In contrast, the latter group lives in a social world in which the state is in the present context a viable commumity. But this entity is in turn absent from the world of those with the local identifications. An attempt by the state to intervene in the council's proposed speecli would thus be experienced and perceived by these individuals as an oppressive intrusion by external forces into the community's internal affairs and hence as a violation of their rights.

If what I have just described is a genuine problein, it is also bound to prove a frustrating one, at least within the confines of this Article. Nothing in the theoretical equipment that I have deployed will help us resolve such conflicts between incommensurate social realities. Yet, I believe it to be a merit of the theory that I have sketched that it permits us to diagnose and articulate this problem even if the theory falls short of providing a solution.

\section{$\mathrm{V}$ \\ CONCLUSION}

As a conclusion, or instead of it, I can summarize the normative structure of collective speecli as analyzed in this Article in the form of a table. The table is self explanatory; in order for it to correspond fully to the preceding discussion, I sliould only add that the collectivities listed in it and the speech riglits assigned to thein pertain to government or state entities as well as to those collectivities tliat belong in tlie "private" domain.

87. This is the position taken by the Supreme Court in holding that "[a] municipality is merely a department of the State, and the State may withhold, grant or withdraw powers and privileges as it sees fit." Trenton v. New Jersey, 262 U.S. 182, 187 (1923). 


\begin{tabular}{|l|c|c|c|}
\hline $\begin{array}{l}\text { type of } \\
\text { speaker's right }\end{array}$ & $\begin{array}{c}\text { original } \\
\text { (expressive) } \\
\text { right }\end{array}$ & $\begin{array}{c}\text { active } \\
\text { derivative } \\
\text { right } \\
\text { collectivity }\end{array}$ & $\begin{array}{c}\text { passive } \\
\text { derivative } \\
\text { right }\end{array}$ \\
\hline $\begin{array}{l}\text { utilitarian organization } \\
\text { expressive organization } \\
\text { protective organization } \\
\text { community }\end{array}$ & ++ & + & + \\
\hline
\end{tabular}

The table conveys in a graphic way, and so accentuates, a property of the discursive exposition that preceded it: it is the neatness of the typology of both collectivities and rights and of their interrelationships. Let ine then sound a warning to which I have already alluded earlier. Any atteinpt to fit a substantial segment of social reality into a table forces sucli reality into a Procrustean bed. The present case is no exception. Many collectivities will no doubt prove recalcitrant in the face of the sharp divisions I propose, and the appropriate constitutional protections will often elude the schematic structure of riglits that I have elaborated. Nonetheless, the theoretical categories witli their relative neatness can help us cope with the morass of social reality. But theoretical clarity will be an aid rather than a trap only so long as it is remembered tliat theory is here designed only to inform judgment and cominon sense, not to replace thein. 
